\title{
Specify Other Risk Factor
}

National Cancer Institute

\section{Source}

National Cancer Institute. Specify Other Risk Factor. NCI Thesaurus. Code C160153.

A directive to specify the other risk factor. 